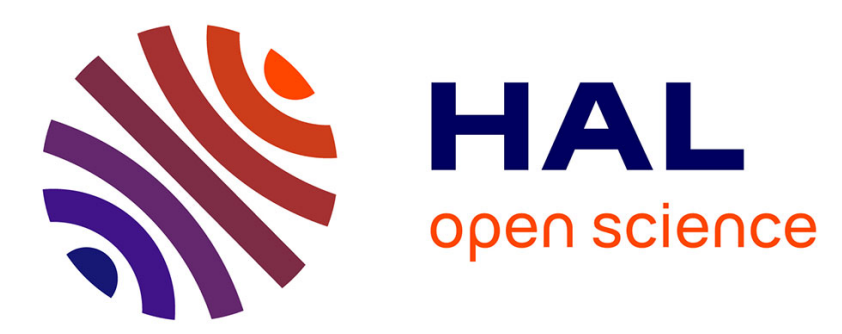

\title{
Plasma anodization of silicon at room temperature
}

\author{
P. Dimitriou, S. Gourrier
}

\section{To cite this version:}

P. Dimitriou, S. Gourrier. Plasma anodization of silicon at room temperature. Revue de Physique Appliquée, 1981, 16 (8), pp.419-424. 10.1051/rphysap:01981001608041900 . jpa-00244935

\section{HAL Id: jpa-00244935 https://hal.science/jpa-00244935}

Submitted on 1 Jan 1981

HAL is a multi-disciplinary open access archive for the deposit and dissemination of scientific research documents, whether they are published or not. The documents may come from teaching and research institutions in France or abroad, or from public or private research centers.
L'archive ouverte pluridisciplinaire HAL, est destinée au dépôt et à la diffusion de documents scientifiques de niveau recherche, publiés ou non, émanant des établissements d'enseignement et de recherche français ou étrangers, des laboratoires publics ou privés. 


\title{
Plasma anodization of silicon at room temperature
}

\author{
P. Dimitriou and S. Gourrier \\ Laboratoires d'Electronique et de Physique Appliquée, 3, avenue Descartes, 94450 Limeil Brevannes, France
}

(Reçu le 19 février 1981, révisé le 8 mai 1981, accepté le 14 mai 1981)

\begin{abstract}
Résumé. - L'anodisation plasma à température ambiante du silicium (vitesses de croissance de quelques $\mathrm{nm} / \mathrm{min}$.) est possible à travers une couche de zircone stabilisée à la chaux (CSZ). La cinétique d'anodisation, la composition, l'aspect et les propriétés électriques des films de $\mathrm{SiO}_{2}$ ainsi obtenus sont décrits dans cet article. Des couches de silice présentant un minimum de rugosité et de défauts structurels sont obtenues par anodisation à tension constante ou à faible courant. Le champ de claquage est environ $5 \times 10^{6} \mathrm{~V} / \mathrm{cm}$. Un recuit en hydrogène à $470^{\circ} \mathrm{C}$ pendant $30 \mathrm{~min}$. amène la densité d'états à l'interface $\mathrm{SiO}_{2} / \mathrm{Si}$ dans la gamme $10^{10}-10^{11} \mathrm{~cm}^{-2} \cdot \mathrm{eV}^{-1}$. La silice obtenue par anodisation plasma à plus haute température (au-dessus de $400^{\circ} \mathrm{C}$ ) présente des propriétés analogues. La zircone stabilisée joue en plus un rôle protecteur contre les contaminations de l'oxyde. Enfin, il est possible d'obtenir des couches de silice épaisses (plus de $0,3 \mu \mathrm{m}$ ) dans des temps raisonnables (30 min.) à température modérée $\left(200^{\circ} \mathrm{C}\right)$.
\end{abstract}

\begin{abstract}
Room temperature plasma anodization of silicon (growth rate of a few $\mathrm{nm} / \mathrm{min}$.) is possible through a thin calcia stabilized zirconia (CSZ) layer. The anodization kinetics, the composition and the electrical properties of the anodic $\mathrm{SiO}_{2}$ films are studied. Constant voltage or low current anodization lead to quasi defect free films with reduced surface roughness. The dielectric breakdown field of as grown $\mathrm{SiO}_{2}$ is about $5 \times 10^{6} \mathrm{~V} / \mathrm{cm}$. The minimum of density of traps at the $\mathrm{SiO}_{2} / \mathrm{Si}$ interface is in the $10^{10}-10^{11} \mathrm{~cm}^{-2} . \mathrm{eV}^{-1}$ range after hydrogen annealing at $470^{\circ} \mathrm{C}$ for $30 \mathrm{~min}$. This is comparable to high temperature (above $400^{\circ} \mathrm{C}$ ) plasma grown $\mathrm{SiO}_{2}$. The protective filter effect of the CSZ against contamination has also been demonstrated. In addition, thick (above $0.3 \mu \mathrm{m}$ ) $\mathrm{SiO}_{2}$ layers can be obtained in a reasonable time (about $30 \mathrm{~min}$.) at moderate temperatures.
\end{abstract}

1. Introduction. - High quality $\mathrm{SiO}_{2}$ thin films, required for integrated circuits technology and M.O.S. devices, are currently formed by thermal oxidation of silicon above $1000^{\circ} \mathrm{C}$. This high temperature process presents several drawbacks such as dopant redistribution, warpage of large wafers, defects formation (dislocations, stacking faults) and the impossibility of using metallizations before the growth.

Operating under high oxygen pressure can decrease the oxidation temperature, but only down to 800 $900^{\circ} \mathrm{C}$. A more significant temperature reduction can be obtained by plasma anodization $[1,2]$ : appreciable growth rates (a few $\mathrm{nm} / \mathrm{min}$.) are observed at temperatures above $400{ }^{\circ} \mathrm{C}-500{ }^{\circ} \mathrm{C}$. On the other hand, plasma anodization is a dry process, which could be automated and integrated in a totally dry device fabrication scheme resulting in improved reproducibility and production yields. However, the anodization rates are negligibly small below $200{ }^{\circ} \mathrm{C}$.

Plasma anodization of silicon between $20^{\circ} \mathrm{C}$ and $100^{\circ} \mathrm{C}$ and a significant increase of the anodization rates of metals like $\mathrm{Al}$ and $\mathrm{Ta}$ have been recently obtained [3] by depositing on the sample surface before anodization a suitable oxygen conducting thin layer which controls the supply of oxygen ions to the sample. Calcia stabilized zirconia (CSZ) has been chosen for this purpose because it is a well known oxygen solid electrolyte which exhibits a high oxygen conductivity via a vacancy type diffusion $[4,5]$. Moreover, stoichiometric and dense CSZ thin films can be deposited by RF sputtering [6].

$\mathrm{SiO}_{2}$ films up to several hundreds of nanometers thick can be obtained in this way with typical rates of a few $\mathrm{nm} / \mathrm{min}$. Clearly, this process can represent a significant improvement to the plasma anodization technique. On the other hand, Rutherford backscattering (RBS) studies show that the oxide grows under the CSZ which remains unchanged during anodization [3]. This indicates that the CSZ is an oxygen filter which can protect the underlying $\mathrm{SiO}_{2}$ film from impurities contamination during growth or annealing.

Preliminary results concerning the room tempe- 
rature plasma grown $\mathrm{SiO}_{2}$ have already been reported [3] and in this paper we present a more complete study of the growth kinetics, the composition and the electrical properties of the $\mathrm{SiO}_{2}$ films.

2. Experimental. - Silicon samples $n$ type (100) $\left(2 \times 10^{15} \mathrm{~cm}^{-3}\right), \mathrm{n}$ type $(111)\left(10^{18} \mathrm{~cm}^{-3}\right)$ and $\mathrm{p}$ type (111) $\left(1-2 \times 10^{15} \mathrm{~cm}^{-3}\right)$ are used in this work.

The samples are first degreased in trichlorethylene, dipped in hydrofluoric acid to remove any native surface oxide, rinced in deionized water and dried. The CSZ film is then deposited by RF sputtering in a pure oxygen plasma from a sintered target using the technique first described by Croset et al. [6]. The CSZ thickness varies from $20 \mathrm{~nm}$ to $80 \mathrm{~nm}$. No post deposition annealing has been made.

The anodizations are carried out in a multipolar oxygen plasma. This plasma source has been described elsewhere [7] and has already been applied to GaAs plasma anodization. It consists essentially of a hot electron emitter (filament) associated with a magnetic confinement produced by permanent magnets. Homogeneous, high density $\left(10^{10}-10^{11} \mathrm{~cm}^{-3}\right)$ plasmas can be produced at low neutral pressures $\left(10^{-3}-10^{-2}\right.$ torr). Uniform oxides over several $\mathrm{cm}^{2}$ can be easily obtained.

The sample is mounted on a copper platform which is temperature regulated (from $20^{\circ} \mathrm{C}$ to $600^{\circ} \mathrm{C}$ ). The sample area exposed to the plasma is defined by a circular alumina cap with an opening of generally $10 \mathrm{~mm}$ in diameter.

Anodizations can be carried out either at constant anodization voltage $V_{\text {a }}$ (potential of the rear side of the sample) or at constant total sample current density $J_{s}$. During typical anodizations, the plasma density is about $1-3 \times 10^{10} \mathrm{~cm}^{-3}$, the plasma potential $V_{\mathrm{p}}$ about $-10 \mathrm{~V}$ and the floating potential $V_{\mathrm{f}}$ (potential of an electrically isolated electrode) about $-35 \mathrm{~V}$. $J_{\mathrm{s}}$ has been varied up to $50 \mathrm{~mA} / \mathrm{cm}^{2}$.

The anodization kinetics can be followed by in situ real time ellipsometry (at $6328 \AA$ ) assisted by a HP 9825 calculator. During our kinetics studies, a $(\Delta, \psi)$ couple is automatically obtained every ten seconds (the measurement time of the system can however be much smaller, less than $1 \mathrm{~s}$ ).

The thicknesses and compositions of the different layers and their interfaces are also determined by spectroscopic ellipsometry [8] (photon energy from 1.6 to $5.4 \mathrm{eV}$ ).

Auger electron spectroscopy associated with $\mathrm{Ar}$ ion milling is used to analyse the composition of the samples before and after anodization.

Some samples are annealed after anodization in nitrogen or hydrogen at temperatures ranging from 400 to $600^{\circ} \mathrm{C}$. Aluminium dots $(200 \mu \mathrm{m}$ in diameter $)$ are then evaporated for electrical characterization. On the major part of one sample, the CSZ has been sputtered off in situ by argon bombardment immediately after anodization (and before annealing).
Capacitance voltage $C(V)$ and conductance voltage $G(V)$ curves are measured using a $C(V)$ plotter PAR 410 connected to a HP 9825 calculator. The density of interface states can be automatically calculated by Terman's capacitance method [9]. Calculations using the Götzberger-Nicollian conductance technique [10] (measurement frequency from $700 \mathrm{~Hz}$ to $1 \mathrm{MHz}$ ) are also performed.

3. Results. - 3.1 Growth KINETICS. - The $\mathrm{SiO}_{2}$ anodization kinetics are deduced from in situ ellipsometry, assuming that the CSZ film is unchanged and remains on top of the structure during anodization [3]. Figure 1 shows the $\mathrm{SiO}_{2}$ thickness and the anodization voltage $V_{\mathrm{a}}$ versus time during anodization at constant current at $70^{\circ} \mathrm{C}$ of a CSZ/Si sample.

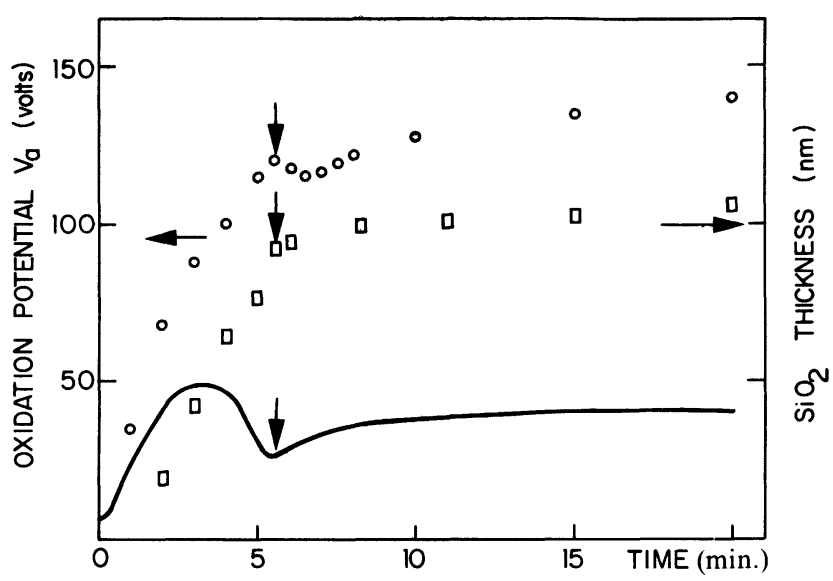

Fig. 1. $-\mathrm{SiO}_{2}$ thickness ( $\square$ ), anodization voltage (O) and experimental cos $\Delta$ (full line) variations versus time during constant current $\left(J_{\mathrm{s}}=13 \mathrm{~mA} / \mathrm{cm}^{2}\right)$ anodization at $70^{\circ} \mathrm{C}$ of a CSZ $(32 \mathrm{~nm}) / \mathrm{Si}$ structure. The vertical arrows indicate the formation of defects in the anodized area.

$110 \mathrm{~nm} \mathrm{SiO}{ }_{2}$ are obtained in about $20 \mathrm{~min}$. Using different plasma and anodization conditions, $\mathrm{SiO}_{2}$ films several hundreds nm thick are easily formed. Without CSZ, comparable results could only been obtained at higher temperatures (above $500^{\circ} \mathrm{C}$ ) [1].

The experimental cos $\Delta$ variations given by the ellipsometry system are also plotted on figure 1 (full line). A sudden change of slope (indicated by an arrow) is observed on this curve (and also on the experimental $\tan \psi$ variations not plotted on the picture), and corresponds to a bump in the anodization voltage curve. Systematic studies show that this can be associated with the formation of structural defects (holes) in the film [3]. These defects are created at first at the centre of the anodized area and then spread out on the whole surface if the anodization is carried on. They can be observed by SEM and have been described previously [3] : their typical diameter is a few microns and spectroscopic ellipsometry measurements indicate that they probably correspond to areas of smaller 
$\mathrm{SiO}_{2}$ thickness (while the $\mathrm{CSZ}$ thickness remains uniform all over the sample surface).

Holes formation is generally observed during constant current anodization with relatively high $J_{s}$ $\left(\geqslant 10 \mathrm{~mA} / \mathrm{cm}^{2}\right)$. In contrast, anodizations at low $J_{\mathrm{s}}\left(\leqslant 5 \mathrm{~mA} / \mathrm{cm}^{2}\right)$ are possible up to relatively large thicknesses $(\geqslant 100 \mathrm{~nm})$ without holes formation. This is in agreement with other results on plasma grown oxides $[11,12]$ : Pulfrey and Reche [12] have reported that compressive stresses lead to $\mathrm{SiO}_{2}$ film breakdown during anodization if the growth is attempted beyond a certain critical thickness, which decreases when the total anodization current increases.

The electric fields of the different layers are calculated as already reported [3] by estimating the surface potential $V_{s}$ of the sample with a flat probe (typical values between $-10 \mathrm{~V}$ and $-15 \mathrm{~V}$ ). In a series of experiments carried out under the same anodization conditions $\left(J_{0}=10 \mathrm{~mA} / \mathrm{cm}^{2}\right)$ the initial field in the CSZ varies from $7 \times 10^{6}$ to $4.6 \times 10^{6} \mathrm{~V} / \mathrm{cm}$ for CSZ thicknesses ranging from 26 to $70 \mathrm{~nm}$. A field of $4 \times 10^{6} \mathrm{~V} / \mathrm{cm}$ has been obtained in reference [3] for CSZ supplied by Thomson CSF films of thicknesses above $70 \mathrm{~nm}$.

Assuming that the voltage drop through the CSZ film remains constant during anodization, the formation field of $\mathrm{SiO}_{2}$ can be calculated. It varies from 1 to $2 \times 10^{7} \mathrm{~V} / \mathrm{cm}$.

Figure 2 shows the growth kinetics at $70{ }^{\circ} \mathrm{C}$ using a constant anodization voltage $\left(V_{\mathrm{a}}=140 \mathrm{~V}\right)$ for a CSZ/Si sample (CSZ thickness $30 \mathrm{~nm}$ ). The total current density $J_{s}$ is also plotted. In this example, $120 \mathrm{~nm} \mathrm{SiO}{ }_{2}$ are obtained in about $25 \mathrm{~min}$. (corresponding to an anodization constant [11] of $0.8 \mathrm{~nm} / \mathrm{V})$.

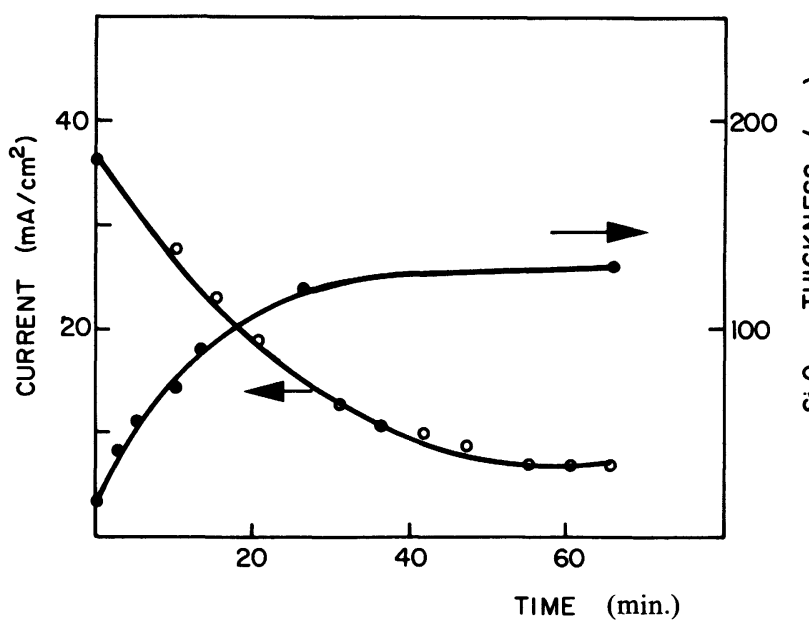

Fig. 2. - Oxide thickness and total sample current as a function of time during constant voltage $\left(V_{\mathrm{a}}=140 \mathrm{~V}\right)$ anodization at $70^{\circ} \mathrm{C}$ for a $\operatorname{CSZ}(30 \mathrm{~nm}) / \mathrm{Si}$ structure.

Figure 3 shows SEM pictures of a CSZ/Si sample (magnification 20000) before and after constant voltage anodization $\left(V_{\mathrm{a}}=140 \mathrm{~V}\right)$. Similar surface
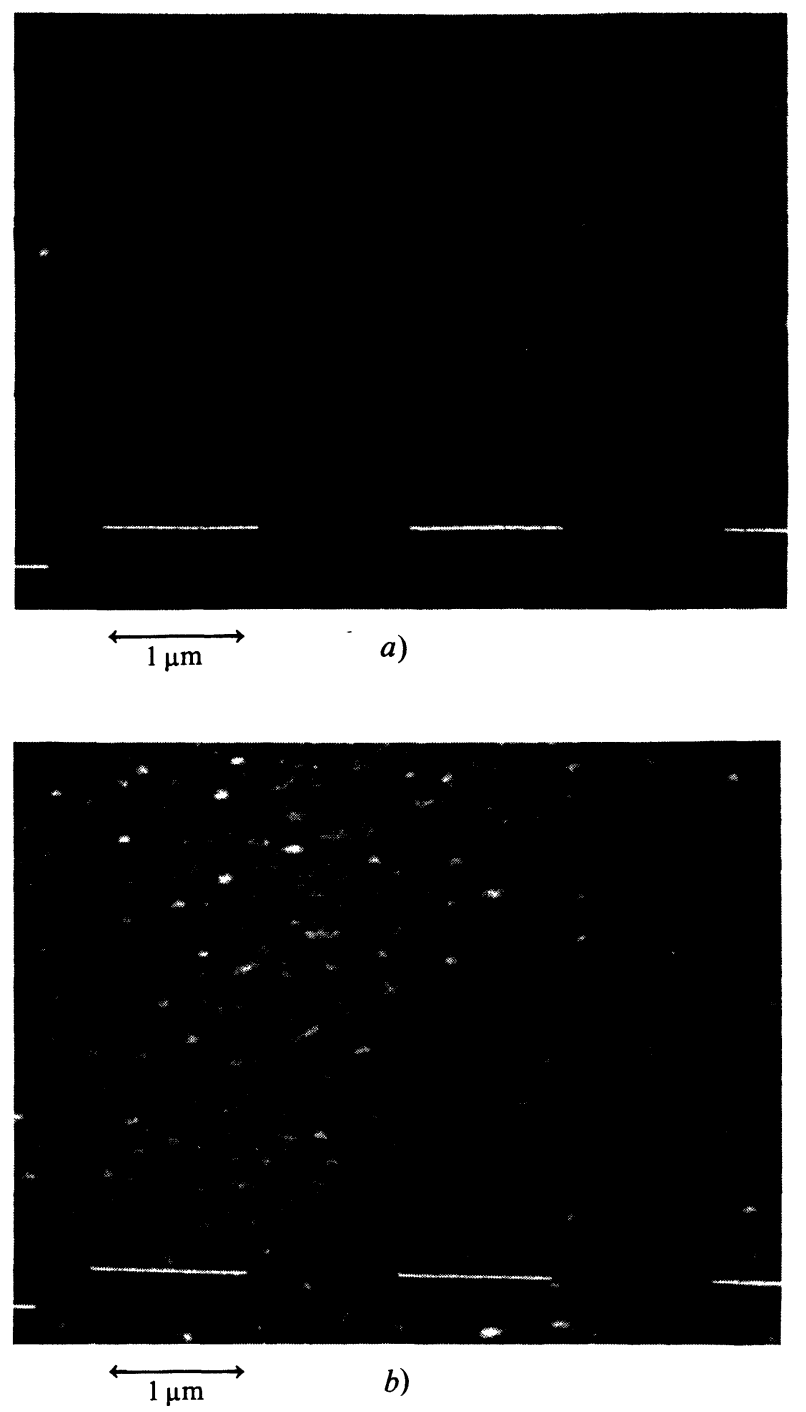

Fig. 3. - SEM picture (magnification 20000 ) of a CSZ/Si sample before $(a)$ and after $(b)$ constant voltage anodization.

aspects were obtained after low current density anodizations (see above). No holes can be seen on the anodized area which is perfectly specular to the naked eye. A small residual surface roughness is only observed on these pictures. The satisfactory surface aspect after constant voltage anodization is also consistent with the observations of Pulfrey and Reche [12] : as the current decreases the critical maximum thickness increases and remains always larger than the actual $\mathrm{SiO}_{2}$ thickness. The good agreement between our observations and those of Pulfrey and Reche indicates that the structural defects are not due to the presence of the CSZ layer but are characteristic of the $\mathrm{SiO}_{2}$ films during anodization.

The samples that will be described further on have been anodized under conditions leading to defect free oxides (constant $V_{\mathrm{a}}$ or low $J_{\mathrm{s}}$ ).

3.2 Composition. - Auger depth profiles of a CSZ/Si sample (50 nm CSZ) before and after anodi- 
zation have been performed. Several conclusions can be drawn :

a) After anodization, the peak to peak heights of the $\mathrm{CSZ}$ constituents $(\mathrm{Ca}, \mathrm{Zr}$ and $\mathrm{O})$ vary by less than $10 \%$. In a previous work [3], RBS studies performed on $\mathrm{CSZ} / \mathrm{Ta}$ and $\mathrm{CSZ} / \mathrm{Al}$ samples indicated that within $3 \%$ there was no decrease of the content of $\mathrm{Ca}$ and $\mathrm{Zr}$ in the CSZ films after anodization.

b) The composition of the CSZ is not homogeneous in depth. This has been repeatedly observed but may be due to migrations during ion milling.

c) The $\mathrm{CSZ} / \mathrm{SiO}_{2}$ interface is relatively sharp (less than $5 \mathrm{~nm}$ ) and no significant outdiffusion of $\mathrm{Si}$ through the CSZ occurs.

The relative sharpness of the interfaces is confirmed by spectroscopic ellipsometry. Interfaces of typical width 5-10 $\mathrm{nm}$ are found between $\mathrm{CSZ}$ and $\mathrm{SiO}_{2}$. The technique is however much more sensitive to the $\mathrm{SiO}_{2} / \mathrm{Si}$ interface because the dielectric functions of $\mathrm{SiO}_{2}$ and $\mathrm{Si}$ are more strongly different than those of $\mathrm{CSZ}$ and $\mathrm{SiO}_{2}$ (both are dielectrics). A five layers model (air $/ \mathrm{CSZ} / \mathrm{SiO}_{2} / \mathrm{SiO}_{2}-\mathrm{Si}$ interface $/ \mathrm{Si}$ ) is used to fit the experimental data (thus neglecting the small influence of the $\mathrm{CSZ} / \mathrm{SiO}_{2}$ interface) and allows for a precise determination of the composition of the $\mathrm{SiO}_{2} / \mathrm{Si}$ interface. Dielectric functions of thermally grown $\mathrm{SiO}_{2}$ and $\mathrm{ZrO}_{2}$ are used as reference to fit the experimental data. The results are presented on figure 4 for a relatively thick $\mathrm{SiO}_{2}$ layer (constant

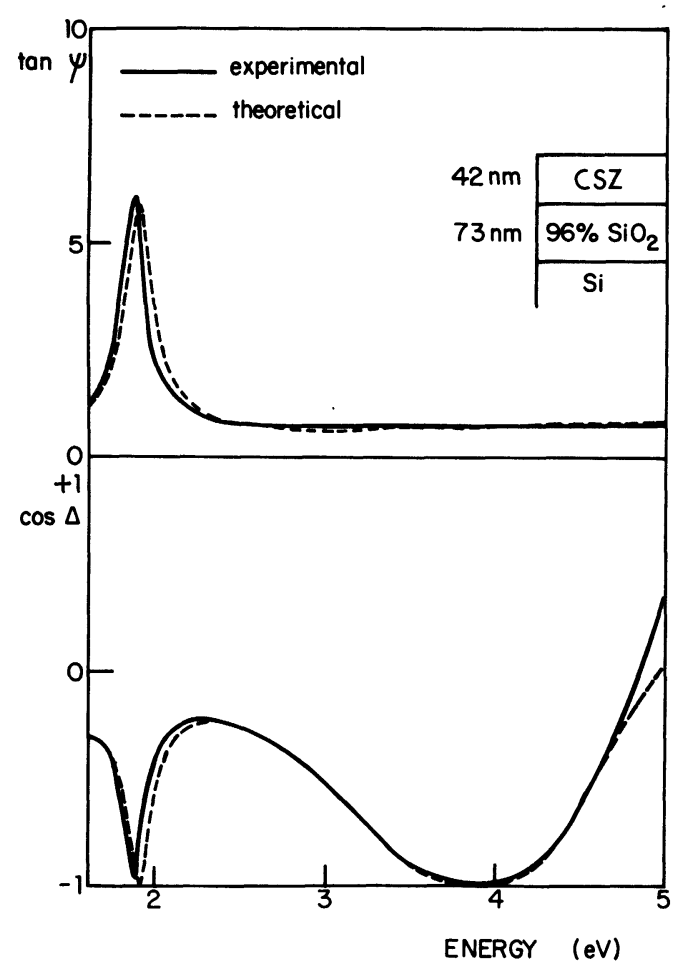

Fig. 4. - Experimental (full line) and theoretical (dashed line) $\tan \psi$ and $\cos \Delta$ curves of an anodized sample. The inset shows the model used for the calculations. voltage anodization). The full line curves are the experimental $\tan \psi$ and $\cos \Delta$ spectra and the dashed line curves the best fit obtained with the five layers model (composition shown on the inset). The $\mathrm{SiO}_{2} / \mathrm{Si}$ interface width is less than $5 \mathrm{~nm}$ in this case (constant $V_{\mathrm{a}}$ ). The oxide film is found to be optically equivalent to $96 \%$ thermally grown $\mathrm{SiO}_{2}$ and $4 \%$ voids.

For constant current anodized samples, the $\mathrm{SiO}_{2} / \mathrm{Si}$ interface width is generally larger than for constant voltage anodized samples. Typical values vary from 10 to $20 \mathrm{~nm}$ and increase with $J_{\mathrm{s}}$ and anodization duration.

3.3 Electrical PROPERTIEs. - The dielectric breakdown field $E_{\mathrm{c}}$ of the $\mathrm{SiO}_{2}$ film (measured on a sample anodized at constant $V_{\mathrm{a}}$ for which the superficial CSZ film had been sputtered off) is about $5 \times 10^{6} \mathrm{~V} / \mathrm{cm}$ for as grown material and decreases to $3 \times 10^{6} \mathrm{~V} / \mathrm{cm}$ and $1.2 \times 10^{6} \mathrm{~V} / \mathrm{cm}$ after hydrogen annealing during $30 \mathrm{~min}$. at $470{ }^{\circ} \mathrm{C}$ and $600{ }^{\circ} \mathrm{C}$ respectively. The dielectric breakdown field of the CSZ is about $4 \times 10^{6} \mathrm{~V} / \mathrm{cm}$ and does not seem to be affected by annealing at $470^{\circ} \mathrm{C}$.

Hydrogen is found to be a more efficient annealing ambient than nitrogen for reducing the trap density at the $\mathrm{SiO}_{2} / \mathrm{Si}$ interface. Figure 5 shows a typical

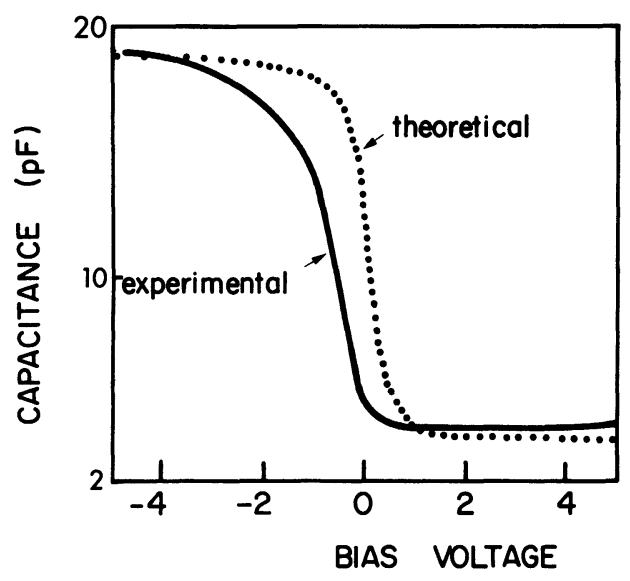

Fig. 5. $-1 \mathrm{MHz} C(V)$ curve of an $\mathrm{Al} / \mathrm{CSZ} / \mathrm{SiO}_{2} / \mathrm{Si}(\mathrm{p}$ doped sample) after annealing at $470^{\circ} \mathrm{C}$ for $30 \mathrm{~min}$. in hydrogen.

$1 \mathrm{MHz} C(V)$ curve of an $\mathrm{Al} / \mathrm{CSZ} / \mathrm{SiO}_{2} / \mathrm{Si}$ sample (p type, impurity concentration of about $3 \times 10^{15} \mathrm{~cm}^{-3}$ ) after hydrogen annealing at $470{ }^{\circ} \mathrm{C}$ for $30 \mathrm{~min}$. and metallization. The distribution of interface states density $N_{\mathrm{ss}}$ deduced from this curve using Terman's : capacitance method is shown on figure 6 . The minimum of $N_{\mathrm{ss}}$ is below $10^{11} \mathrm{~cm}^{-2} \cdot \mathrm{eV}^{-1}$ which is the sensitivity limit of the capacitance method. Comparable results are found on $\mathbf{n}$ type samples. A more extensive study using the Götzberger-Nicollian conductance technique [10] (from $700 \mathrm{~Hz}$ to $1 \mathrm{MHz}$ ), confirms that the minimum of $N_{\mathrm{ss}}$ lies in the $10^{10}$. $10^{11} \mathrm{~cm}^{-2} \cdot \mathrm{eV}^{-1}$ range. Similar values are found 


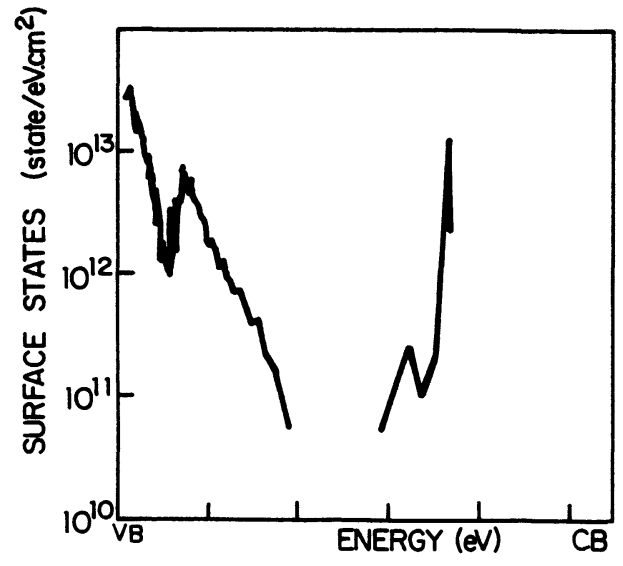

Fig. 6. - Interface state density distribution in the forbidden band gap $(1.1 \mathrm{eV})$ as deduced from figure 5 using the capacitance method.

by $\mathrm{T}$. Sugano [1] for plasma grown (at $600^{\circ} \mathrm{C}$ ) $\mathrm{SiO}_{2}$ after annealing in forming gas at $450^{\circ} \mathrm{C}$. Th:s density is about one order of magnitude higher than for currently produced thermal oxides but may probably be reduced by more appropriate annealing conditions.

Post metallization annealing in nitrogen at $350^{\circ} \mathrm{C}$ increases the interface states density and the hysteresis of the $C(V)$ curves of hydrogen annealed samples, probably because of the outdiffusion of hydrogen, a phenomenon commonly observed for thermally grown $\mathrm{SiO}_{2}$ samples.

The presence of the CSZ film has a strong influence on the $C(V)$ curves. Figure 7 presents $1 \mathrm{MHz} C(V)$ curves taken on the same sample (annealed at $470{ }^{\circ} \mathrm{C}$ in hydrogen for $30 \mathrm{~min}$.) on areas covered with $\operatorname{CSZ}(a)$ and on areas where the CSZ has been sputtered off $(b)$. The $C(V)$ curve of the CSZ covered area is measured at the edge of the anodized surface where the $\mathrm{SiO}_{2}$ thickness is smaller (by $10 \%$ ) than in the rest of the sample. The accumulation capacitance is therefore

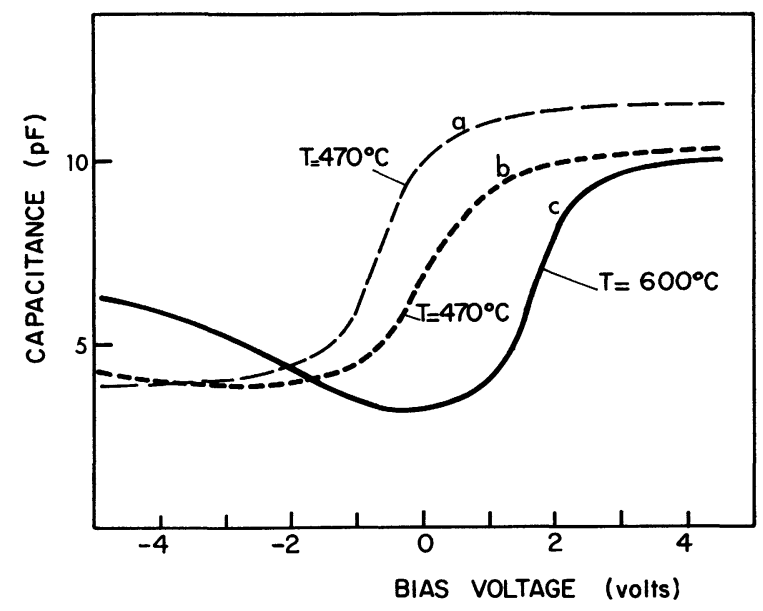

Fig. 7. $-1 \mathrm{MHz} C(V)$ curve with $\operatorname{CSZ}(a)$ and without $(b)$ taken on the same sample after hydrogen annealing at $470{ }^{\circ} \mathrm{C}$ for $30 \mathrm{~min}$. (n doped Si, $2 \times 10^{15} \mathrm{~cm}^{-3}$ ). Curve (c) corresponds to hydrogen annealing at $600{ }^{\circ} \mathrm{C}$ for $30 \mathrm{~min}$. of the uncovered area. larger in spite of the presence of the superficial CSZ layer. A flat band shift towards positive voltage is observed on the area without CSZ, indicating the presence of negative charges (density about $3 \times 10^{11} \mathrm{~cm}^{-2}$ ) in the $\mathrm{SiO}_{2}$ layer. These charges also explain the apparent low frequency behaviour [13] of the $C(V)$ curve at negative bias (increase of the capacitance in the inversion region). Curve $c$ of figure 7 shows the $C(V)$ curve taken on the uncovered area after annealing in hydrogen at $600{ }^{\circ} \mathrm{C}$ for $30 \mathrm{~min}$. The flat band shift and the apparent low frequency behaviour are stronger, indicating that the negative charge density has increased during thermal treatments (however the interface state density seems to be further reduced). Most probably, oxide contamination occurs during annealing. The CSZ film prevents or strongly reduce this contamination and acts as a protective filter layer.

The presence of the CSZ increases the hysteresis width of the $C(V)$ curves : for a voltage swing of $-10 \mathrm{~V}$ to $10 \mathrm{~V}$ and sweep rates between $0.01 \mathrm{~V} / \mathrm{s}$ and $5 \mathrm{~V} / \mathrm{s}$ the hysteresis width is about $0.4 \mathrm{~V}$ and $0.1 \mathrm{~V}$ for areas with and without CSZ respectively.

4. Discussion. - The mechanism of anodization rate enhancement is still unknown. Two hypothesis may be invoked (or a combination of both) : 1) the surface chemistry at the CSZ/plasma interface tends to favour the formation and capture of the oxygen ions required for the oxide growth; 2) the supply of oxygen ions to the substrate is significantly increased because of a high bulk ionic conductivity. In fact, surface phenomena are probably determinant for several reasons :

- bulk CSZ exhibits a significantly high oxygen ion conductivity above $500^{\circ} \mathrm{C}$. This is due to the stabilization of the fluorite structure of the crystal and the high vacancy concentration $(5-10$ mole $\%)$ produced by the substitution of $\mathrm{Ca}^{2+}$ to $\mathrm{Zr}^{4+}$ on the metal sites [4]. However, the activation energy of the process is large $(1.1-1.2 \mathrm{eV})$ and room temperature conductivity is extremely small;

- proper post deposition annealing is generally required for the RF sputtered CSZ thin films to exhibit the same conductivity than bulk material. For our application, no post deposition annealing was necessary ;

- room temperature plasma anodization of silicon occurs under very thin (less than $30 \mathrm{~nm}$ ) CSZ films. These layers are probably amorphous [14] and discontinuous and a large bulk conductivity seems unlikely.

Moreover, recently reported experiments [15] confirm the importance of surface chemistry in the oxidation process.

5. Conclusion. - The properties of room temperature plasma grown $\mathrm{SiO}_{2}$ appear quite similar to those 
of higher temperature (above $400^{\circ} \mathrm{C}$ ) plasma grown $\mathrm{SiO}_{2}[1,2]$. Using constant voltage anodization, defect free films are obtained. The dielectric breakdown field of the as grown film is about $5 \times 10^{6} \mathrm{~V} / \mathrm{cm}$. The minimum of the density of traps at the $\mathrm{SiO}_{2} / \mathrm{Si}$ interface has been reduced in the $10^{10}-10^{11} \mathrm{~cm}^{-2} . \mathrm{eV}^{-1}$ range by annealing in hydrogen at $470{ }^{\circ} \mathrm{C}$. This density is still higher than for thermally grown $\mathrm{SiO}_{2}$, but may be improved by more appropriate annealings. However at the present stage, the achievement of a M.O.S. quality $\mathrm{SiO}_{2}$ would still require much additional work.

Other applications of this new technological process appear attractive :

- because of the filter effect of the $\mathrm{CSZ}, \mathrm{SiO}_{2}$ layers free from impurity contamination can be obtained (in fact, protection from contamination during annealing has been observed in the present work);

- the considerable enhancement of the anodization rate under the CSZ can lead at moderate $\left(200^{\circ} \mathrm{C}\right)$ temperature to the formation of thick $(0.3-1 \mu \mathrm{m})$ $\mathrm{SiO}_{2}$ layers which could be used as insulating areas between components of integrated circuits.

Acknowledgments. - The authors are very grateful to J. B. Theeten, J. Siejka, J. Perrière and M. Croset for valuable discussions. Thanks are also due to J. C. Nurit and J. Magniant for CSZ deposition, M. Erman for spectroscopic ellipsometry measurements, F. Simondet and J.-Y. Aupied for Auger studies, M. Steers for SEM pictures and R. Meunier and C. Blanjot for mechanical and technical assistance.

\section{References}

[1] Ho, V. Q. and Sugano, T., Proc. of the 1979 Int. Conf. on Solid State Devices, Jpn J. Appl. Phys. Suppl. 19-1 (1980) 103:

[2] Chang, R. P. H., Chang, C. C. and Darack, S., Appl. Phys. Lett. 36 (1980) 399.

[3] Gourrier, S., Dimitriou, P., Theeten, J. B., Perrière, J., Siejka, J. and Croset, M., Appl. Phys. Lett. 38 (1981) 33.

[4] Whittingham, M. S., Electrochim. Acta 20 (1975) 575.

[5] Patterson, W., J. Electrochem. Soc. 118 (1971) 1033.

[6] Croset, M., Schnell, J. P., Velasco, G. and Siejka, J., J. Appl. Phys. 48 (1977) 775.

[7] Gourrier, S., Mircea, A. and BaCAL, M., Thin Solid Films 65 (1980) 315.

[8] Theeten, J. B. and Aspnes, D. E., Thin Solid Films 60 (1979) 183.
[9] Terman, L. M., Solid State Electron. 5 (1962) 285.

[10] Nicollian, E. H. and GötzBeRgER, A., Bell Syst. Tech. J. 41 (1964) 803.

[11] O'Hanlon, J. F., in Oxides and oxide films 5, A. K. Vijh Editor (Marcel Decker Inc., New York and Basel) 1977, p. 105.

[12] Pulfrey, D. L. and Reche, J. J., Solid State Electron. 17 (1974) 627.

[13] Sze, S. M., in Physics of Semiconductor Devices (J. Wiley and Son) 1969.

[14] Perrière, J., Private Communication.

[15] Cros, A., Salvan, F., Commandre, M. and Derrien, J., to be published in Surf. Sci. Letters. 